\title{
A new species of Microglanis (Siluriformes: Pseudopimelodidae) a from the Pacific slope of Ecuador
}

Correspondence: Ibon Tobes ibontobes@uti.edu.ec

Submitted May 19, 2019

Accepted Jun 1, 2020

by Juan Marcos Mirande

Epub Jun 26, 2020

\section{${ }^{\circ}$ Ibon Tobes ${ }^{1},{ }^{\oplus}$ Ana Falconí-López ${ }^{1},{ }^{\oplus}$ Jonathan Valdiviezo-Rivera ${ }^{2}$ and ${ }^{\circ}$ Francisco Provenzano-Rizzi ${ }^{3}$}

A new species of catfish is described from the Esmeraldas River Basin, Pacific slope, northern Ecuador. Tentatively included in Microglanis, represents the second species of the genus inhabiting the Trans-Andean region. The new species is distinguished from known congeners by a unique combination of external characteristics: head and body color pattern, uniform, pale brown, yellowish or grayish, without any kind of blotches, bands or dots, only a lunate transverse band, dark or black, at caudal-fin origin; adipose-fin origin and forward without lighter or luminous areas. Compared with M. variegatus, the new species has morphometric differences, such as the distances between dorsal and pelvic fins, and between posterior nostrils. Some osteological characteristics are compared with those observed in species of Pseudopimelodidae inhabiting the Pacific versant of Colombia and Ecuador and with some other species of Microglanis.

Keywords: Diversity, Richness, Systematic, Taxonomy, Trans-Andean region.
Online version ISSN 1982-0224

Print version ISSN 1679-6225

Neotrop. Ichthyol.

vol. 18, no. 2, Maringá 2020
1 Centro de Investigación de la Biodiversidad y Cambio Climático (BioCamb) e Ingeniería en Biodiversidad y Recursos Genéticos, Facultad de Ciencias de Medio Ambiente, Universidad Tecnológica Indoamérica, Machala y Sabanilla, EC170301 Quito, Ecuador. (IT) ibontobes@uti.edu.ec (corresponding author); (AFL) afalconi@uti.edu.ec.

2 Instituto Nacional de Biodiversidad-INABIO, 170135 Quito, Ecuador. (JVR) bioictiojona@yahoo.com.

3 Departamento de Biología, Facultad de Ciencias, Escuela Politécnica Nacional-EPN, 170109 Quito, Ecuador. (FPR) fprovenz@gmail.com. 
Se describe una nueva especie de bagre para la cuenca del río Esmeraldas, vertiente del Pacífico, en el norte de Ecuador. Incluida tentativamente en Microglanis, representa la segunda especie del género que habita en la región transandina. La nueva especie se distingue de los congéneres conocidos por una combinación única de características externas, que incluyen: patrón de color de la cabeza y el cuerpo, uniforme, marrón pálido, amarillento o grisáceo, sin ningún tipo de manchas, bandas o puntos, excepto una banda transversal alunada, oscura o negra, en el origen de la aleta caudal; origen de la aleta adiposa y región anterior sin áreas más claras o luminosas. En comparación con $M$. variegatus, la nueva especie tiene diferencias morfométricas, como las distancias entre las aletas dorsal y pélvica, y entre las narinas posteriores. Algunas características osteológicas se comparan con las observadas en especies de Pseudopimelodidae que habitan en la vertiente del Pacífico de Colombia y Ecuador, y en algunas otras especies de Microglanis.

Palabras clave: Diversidad, Región Transandina, Riqueza, Sistemática, Taxonomía.

\section{INTRODUCTION}

Microglanis Eigenmann, 1912 is the most diverse and geographically widespread genus of family Pseudopimelodidae. Currently, includes 29 described species, all exclusive to South America, that range from Venezuela and Guyana to Argentina, and in the TransAndean region of Ecuador, being the SE Brazil the richest area (Ruiz, 2016; Shibatta, 2016; Fricke et al., 2020). Usually, species of the genus inhabit small creeks with crystal clear waters and slow currents, in holes or where submerged leaves, branches, and tree trunks accumulate, with pebbles and stones (Ruiz, 2016).

Diagnostic characteristics for the genus include: small-sized (standard length up to $80 \mathrm{~mm}$ ); variable color pattern, always includes dark brown blotches, bands, or dots; premaxillary tooth plate without evident projections backward; short or incomplete lateral line (anteriorly, a canal with pores followed posteriorly by free neuromasts, in longitudinal midline); eyes covered by skin; pectoral-fin with five to six branched rays; spines of dorsal and pectoral fins well-developed; and absence of axillary pores (Eigenmann, 1912; Mees, 1974; Shibatta, 2003, 2016; Ruiz, Shibatta, 2010; Ruiz, 2016). Some osteological characteristics of the genus include: mesethmoid bifurcated anteriorly; anterior fontanel large, oval-shaped, extends slightly beyond posterior border of eyes; posterior fontanel, on the supraoccipital, circular and small; frontal with lateral margin long and concave, at eyes level; cleithrum with posterior process slender and pointed; mesocoracoid arch filamentous; and gill rakers, elongated and conical (Ruiz, Shibata, 2010; Ruiz, 2016).

Microglanis poecilus Eigenmann, 1912 is the type species, described for Packeoo Falls, Essequibo River, Guyana. Three species are present in northern South America: $M$. poecilus Eigenmann, 1912, in Guyana; M. secundus Mees, 1974, in Suriname; and M. iheringi Gomes, 1946, in Venezuela. Three species have been described for Andes region of Ecuador and Peru: one Trans-Andean, M. variegatus Eigenmann, Henn, 1914, 
in the Guayas River of Ecuador; and two Cis-Andeans, M. pellopterygius Mees, 1978, in the Aguarico River of Ecuador, and M. zonatus Eigenmann, Allen, 1942, in the Morona River of Peru. Remainder species are Cis-Andean: from Argentina, Brazil (mostly southeast), Paraguay, and Uruguay (Steindachner, 1880; Boulenger, 1891; Ahl, 1936; Bizerril, Perez-Neto, 1992; Malabarba, Mahler, 1998; Bertaco, Cardoso, 2005; Shibatta, Benine, 2005; Sarmento-Soares et al., 2006; Alcaraz et al., 2008; Ottoni et al., 2010; Ruiz, Shibatta, 2010, 2011; Jarduli, Shibatta, 2013; Shibatta, 2014, 2016; Ruiz, 2016; Terán et al., 2016). Microglanis variegatus is sited only in the Guayas River basin, Pacific slope of Ecuador (Barriga, 2012; Jiménez-Prado et al., 2015).

Despite the number of described species, there is not a phylogenetic approach for the genus to date. Some species-groups have been described based, only on external morphological characteristics (Ruiz, 2016). Osteological data of the species of Microglanis are scarce, some are provided in the original descriptions of species (Ortega-Lara, Lehmann, 2006; Sarmento-Soares et al., 2006; Mattos et al., 2013). Ruiz (2016) evaluated the diagnostic characters commonly used to identify Microglanis and highlighted the need for osteological studies and phylogenetic analysis to accurately establish genus status and the relationship between species.

During a research project for the study of river ecology and fish diversity at the Pachijal River basin, NW Quito, 18 specimens tentatively identified as a new Microglanis were captured; herein the description of this new species is presented.

\section{MATERIAL AND METHODS}

Fish sampling was conducted by electrofishing (Hans Grassl model IG200/2D, 300-600 V, 0.2-2 A). Specimens were anesthetized using lidocaine, fixed with formalin (10\%) and preserved in ethanol (70\%). Specimens were separated into types and non-types according to their condition after fixation. For description and comparative analyses, the holotype and 12 paratypes were used. For comparation with Batrochoglanis transmontanus (Regan, 1913), Cruciglanis pacifici Ortega-Lara, Lehmann, 2006 and the species of Microglanis, original descriptions and figures were used, as well as other available references (Eigenmann, Henn, 1914; Gomes, 1946; Sarmento-Soares et al., 2006; Mattos et al., 2013; Shibatta, 2014, 2016; Ruiz, 2016). Additionally, direct comparisons were done with specimens of Batrochoglanis transmontanus and Microglanis variegatus, listed on the examined material.

Body measurements, meristics and observations on external morphology were made using a stereomicroscope. Measurements were taken on the left side, whenever as possible, point-to-point with a digital caliper with an accuracy of $0.1 \mathrm{~mm}$. Twenty-two morphometric measurements were taken, following Shibatta (2016) and Shibatta, Vari (2017). Measurements are expressed as percentage of standard length (SL) or head length (HL). Meristic data included counts of dorsal, pectoral, pelvic, anal, and caudal-fin rays as well as lateral line pores. The frequency of counts obtained is shown throughout text in parentheses and the asterisk denotes holotype values. Twenty-eight morphometric measurements were taken for the new species and compared with identical measures taken on 12 newly captured specimens of Microglanis variegatus (Tabs. 1-2).

Analyses of some osteological characteristics were conducted using two specimens 
(MECN-DP-3762, 39.5 and $51.4 \mathrm{~mm} \mathrm{SL}$ ) prepared, stained (C, S) and adapted from Taylor, Van Dyke (1985). Osteological nomenclature follows literature (Ortega-Lara, Lehmann, 2006; Sarmento-Soares et al., 2006; Mattos et al., 2013). Observations on osteology include neurocranium components, the premaxillary tooth plate, the Weberian apparatus complex, counts of vertebral centra (free centra and the caudal compound as a single element), pleural ribs, branchiostegal rays, and pectoral-fin spine serrations. Museum acronyms from examined comparative material follow Sabaj (2016).

\section{RESULTS}

\section{Microglanis berbixae, new species}

urn:lsid:zoobank.org:act:642C180E-624E-4A11-A81F-3FEA7981E04D

(Fig. 1, 3-7, Tab. 1)

Holotype. MECN-DP-3944, 54.2 mm SL, male, Ecuador, Pichincha Province, Parroquia de Pacto, Quebrada Sune, a tributary of Pachijal River, Esmeraldas River Basin, Pacific slope, 005’28.56”N 7853’53.04”W, 960 masl, 3 Jul 2017, I. Tobes, A. Falconí-López, J. Valdiviezo-Rivera, and F. Provenzano-Rizzi.

Paratypes. MECN-DP-3765, 4, 34.9-53.5 mm SL, same data as holotype. FMNH 135030, 2, 36.5-52.1 mm SL, same subsequent data as holotype. MZUSP 123411, 2, 34.9-40.0 mm SL, same subsequent data as holotype. MEPN 19262, 2, 42.2-47.8 mm SL, same subsequent data as holotype. MECN-DP-3762, 4 (2 C, S), 39.5-51.4 mm SL, same subsequent data as holotype except for the collection date of 19 Aug 2016.

Non-types. MECN-DP-3763, 2, 41.3-43.3 mm SL, same subsequent data as holotype except for the collection date of 19 Aug 2016. MECN-DP-3764, 1, $48.4 \mathrm{~mm}$ SL, Ecuador, Pichincha Province, Parroquia de Pacto, Mashpi Community, a tributary of Mashpi River, Pachijal River Basin, Esmeraldas River Basin, Pacific slope, 0¹0’52.20”N 7854’42.24”W, 539 masl, 14 Aug 2015, I. Tobes, R. Miranda, B. RíosTouma and A. Morabowen.

Diagnosis. Microglanis berbixae is distinguished from congeners by its color pattern. Head and body uniform, pale brown, yellowish or grayish, without any kind of blotches, bands, or dots, except a transverse lunate band, dark brown or black, at caudal-fin origin $v$ s. head and body mottled or marbled brown with whitish or cream blotches, bands, or dots in other species (Figs. 1-3). Microglanis berbixae is further distinguished from $M$. variegatus, its geographically closest species, by belly pigmentation; in $M$. berbixae the belly color is uniform, yellowish or grayish brown, without aggregates of small black dots (melanophores), while M. variegatus usually possesses a whitish or creamy belly with randomly arranged aggregates of melanophores (Figs. 2-3).

In $M$. berbixae, fin-rays have very thin stripes, parallel, black or dark, while in $M$. variegatus, fin-rays have random patterns of dark spots. In M. berbixae, the adipose-fin 


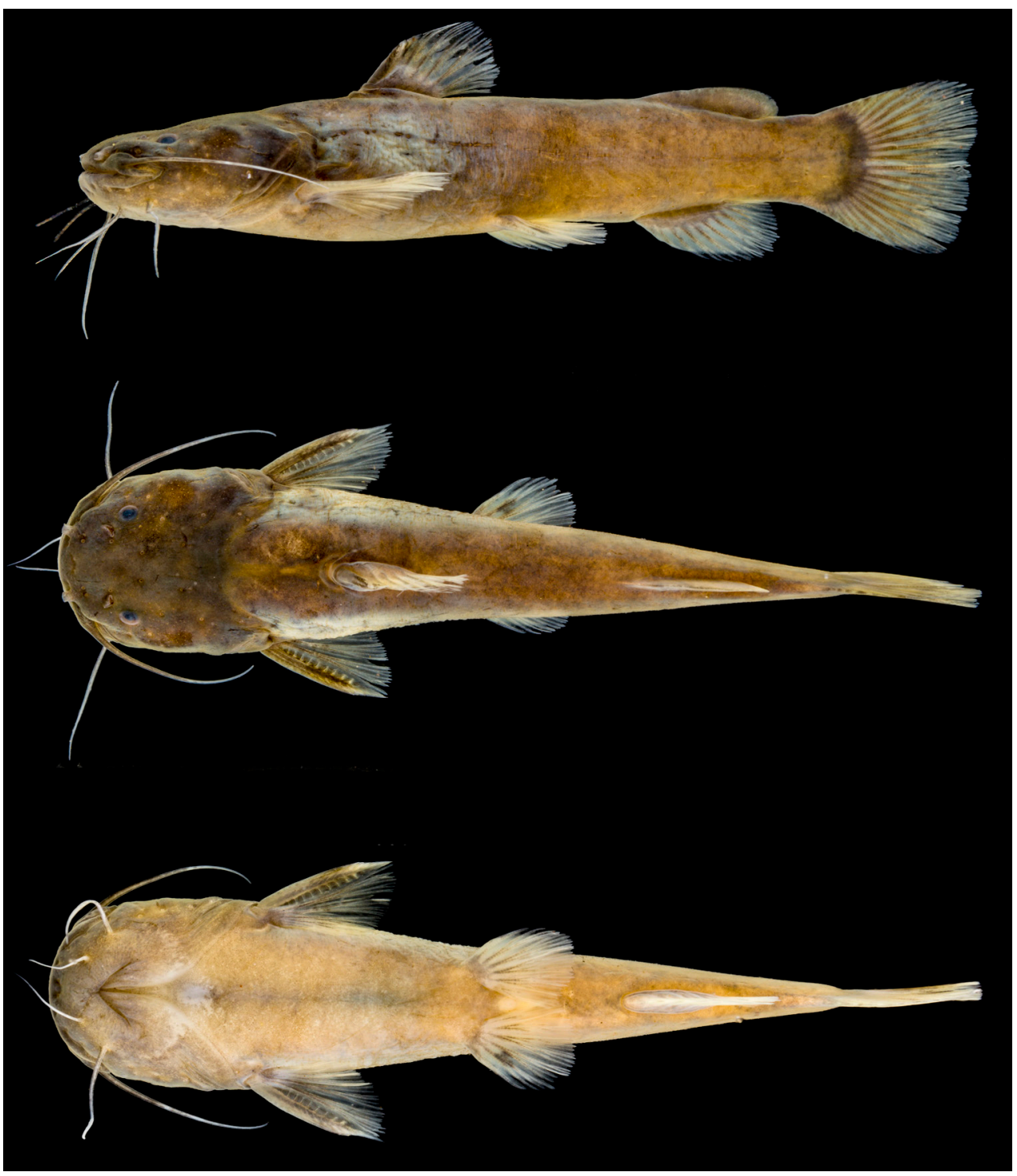

FIGURE 1 I Microglanis berbixae new species, MECN-DP-3944, holotype, male 54.2 mm SL.

origin and anterior area are normal, while in M. variegatus, these areas are notably lighter or luminous (Figs. 1-3). Specimens of M. berbixae may have two or three black spots on adipose-fin, not observed in specimens of $M$. variegatus. Additionally, M. berbixae have higher values of distance between dorsal and pelvic fins than M. variegatus (24.4\%-28.8\% SL and $22.0 \%-24.1 \%$ SL, respectively) and between posterior nostrils (40.5\%-52.3\% HL and $24.4 \%-30.6 \%$ HL, respectively).

Description. Morphometric data are summarized in Tab. 1. Small-sized species, maximum size recorded $54.2 \mathrm{~mm}$ SL. Body depressed from snout tip to dorsal-fin origin, progressively compressed to caudal-fin base. Highest body depth at dorsal-fin origin and largest body width at pectoral-fin origin. Lateral line short, reach pelvicfin origin, with 8 or $9\left(^{\star}\right)$ pores. Contour of ventral surface of head and body almost 


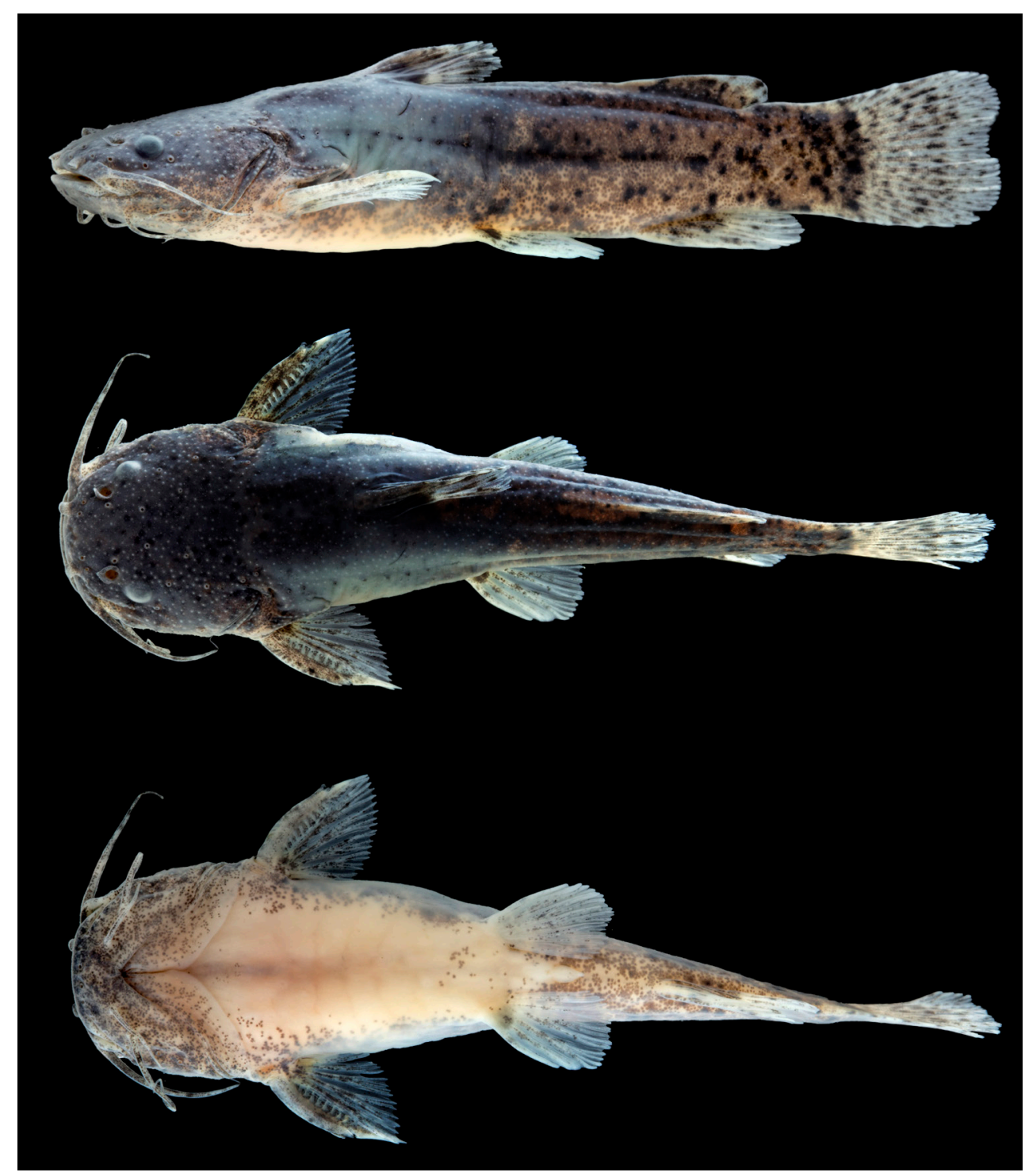

FIGURE 2 I Microglanis variegatus, MECN-DP 4259, male, 37.9 mm SL.-

flat or slightly convex until anal-fin origin, and then slightly concave posteriorly (Fig. 1). Anus and urogenital papilla are differentiable. Papilla located behind the anus as a thickened fleshy tube, with variable shape between sexes (see "Sexual dimorphism" section).

Head depressed, anteriorly rounded in dorsal view. Eyes small, more dorsal than lateral, closer to mouth than to distal margin of operculum, located near the first third of head length, covered by skin, and without free orbital margin. Snout short. Anterior nostril tubular, closer to upper lip than to eye; posterior nostril near anterior margin of eye, possess an anterior flap (Fig. 1).

Mouth wide, terminal. Teeth villiform, curved backward. Gill membrane free from isthmus, with nine branchiostegal rays. All barbels thin, flattened in cross-section. One maxillary pair, two mental pairs. Maxillary barbel medium-sized, reaching or slightly 


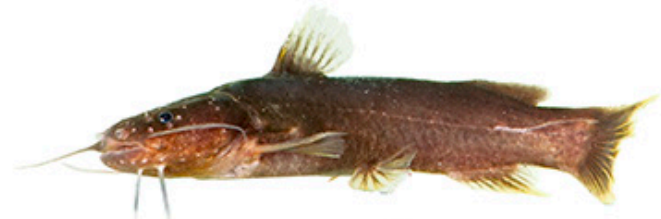

A

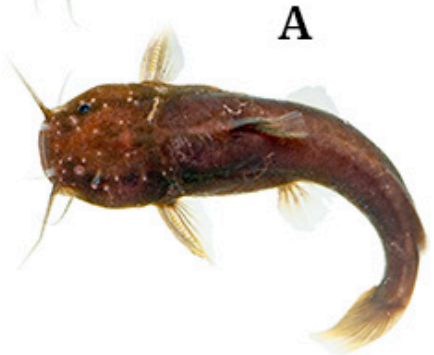

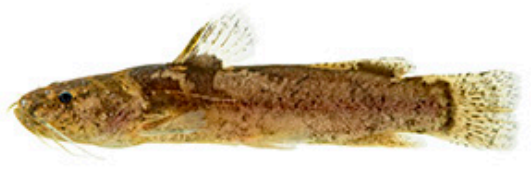

B

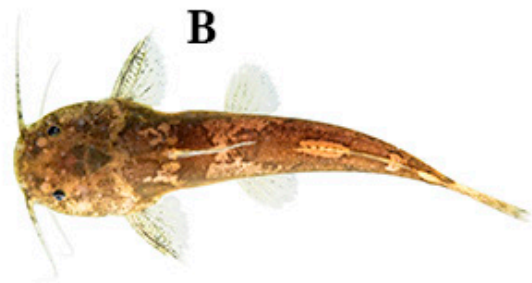

FIGURE 3 I Color pattern in live specimens. A. Microglanis berbixae, MECN-DP-3764, 48.4 mm SL. B. Microglanis variegatus, MZUTI-P-000626, 35.66 mm SL.

surpassing pectoral-fin base. Outer mental barbel not reaching pectoral-fin base; inner mental barbel shorter, reaching almost half-length of outer mental barbel (Fig. 1).

Dorsal-fin I,6 rays $\left(13^{\star}\right)$, located anterior to half of body length, posterior margin rounded, spinelet present. Dorsal-fin spine straight, strong and without hooks, shorter than first four branched rays. Adipose-fin fleshy and elongated, with free posterior margin, its origin opposite to anal-fin origin and its base a little longer than anal-fin base. Pectoral-fin I,6 rays $\left(12^{\star}\right)$, I,5 (1), slightly triangular, when adpressed, not reaching pelvic-fin origin. Pectoral-fin spine strong, slightly flattened and curved, shorter than first two branched rays, with serrations on both margins, anterior serrations partially or weakly developed compared with posterior ones. Pelvic-fin rounded, i,5 rays $\left(13^{\star}\right)$. Pelvic-fin origin at vertical line posterior to base of last branched dorsal-fin ray, when adpressed not reaching anal-fin origin. Anal-fin short with rounded margin, its base shorter than adipose-fin base and not confluent posteriorly with caudal-fin, ii,10 $\left(13^{\star}\right)$. Caudal-fin truncate, $9,10(1)$ or $10,10\left(12^{\star}\right)$ principal rays and $7 / 4$ procurrent rays $\left(13^{\star}\right)$.

Osteological characters. In dorsal and ventral views of mesethmoid, the anterior edge bifurcates and forms conspicuous cornuas (Fig 4). In dorsal view, central area of posterior edge constitutes the anterior margin of anterior cranial fontanelle; laterally, the posterior edge articulates with frontals (Fig. 4A). In ventral view, behind cornuas, bone widens and shows lateral projections smaller than cornuas, with a slightly concave anterior border (Fig. 4B). These projections are visible in both views (Fig. 4). Ventrally, the articulation between mesethmoid and vomer is not visible, both bones are firmly united or fused, cannot be separated. Thus, the presence of a mesethmoidvomer complex is possible (Fig. 4B). In ventral view, the posterior edge shows elongated and pointed middle projection, which is part of the articulation between vomer and parasphenoid (Fig. 4B). Anterior cranial fontanelle is large, oval or elliptical, and nearly $33 \%$ of its length is located on the mesethmoid (Fig. 4A).

Premaxillary tooth plate trapezoidal-shaped, its distal border wide, truncate and 
TABLE 1 I Morphometric data of best-preserved specimens of Microglanis berbixae, expressed as percentages of standard length and percentages of head length, $n=13$ (SD: standard deviation) (range and SD include holotype).

\begin{tabular}{|c|c|c|c|c|c|c|}
\hline & Characters & Holotype & Min & Max & Mean & \pm SD \\
\hline SL & Standard Length (mm) & 54.2 & 34.9 & 54.2 & & \\
\hline \multicolumn{7}{|c|}{ Percents of Standard Length } \\
\hline HL & Head length & 26.7 & 23.8 & 30.0 & 26.8 & 1.9 \\
\hline PL & Pelvic fin length & 15.4 & 14.6 & 18.9 & 16.3 & 1.5 \\
\hline DBL & Dorsal-fin spine length & 9.7 & 9.6 & 12.3 & 10.9 & 0.9 \\
\hline PSL & Pectoral-fin spine length & 13.8 & 11.7 & 15.4 & 13.6 & 1.3 \\
\hline LPCP & Length of postcleithral process & 9.1 & 7.8 & 10.8 & 9.0 & 0.9 \\
\hline PDD & Predorsal distance & 37.7 & 35.0 & 41.9 & 38.0 & 1.8 \\
\hline PPL & Prepelvic length & 52.8 & 50.0 & 53.8 & 51.9 & 1.2 \\
\hline AAnD & Anus to anal fin distance & 11.9 & 9.9 & 17.4 & 13.9 & 2.0 \\
\hline CPL & Caudal peduncle length & 15.2 & 13.1 & 18.5 & 15.6 & 1.4 \\
\hline $\mathrm{CPD}$ & Caudal peduncle depth & 12.7 & 11.2 & 14.2 & 13.1 & 1.0 \\
\hline $\mathrm{BD}$ & Body depth & 20.1 & 18.6 & 25.7 & 22.0 & 2.1 \\
\hline DBL & Dorsal-fin base length & 9.7 & 9.6 & 12.3 & 10.9 & 0.9 \\
\hline AdBL & Adipose-fin base length & 17.2 & 15.6 & 20.1 & 18.1 & 1.4 \\
\hline AnBL & Anal-fin base length & 12.4 & 11.9 & 15.6 & 13.2 & 1.0 \\
\hline $\mathrm{DP}$ & Distance between pelvic fins & 11.9 & 8.9 & 12.0 & 10.7 & 0.9 \\
\hline DPA & Distance from pelvic fin to anus & 10.0 & 7.9 & 10.7 & 9.2 & 0.7 \\
\hline PAD & Pelvic to anal fin distance & 19.8 & 18.0 & 23.6 & 20.6 & 1.7 \\
\hline DDP & $\begin{array}{l}\text { Distance between the dorsal and pelvic } \\
\text { fins }\end{array}$ & 24.7 & 24.4 & 28.3 & 26.2 & 1.5 \\
\hline PGW & Pectoral girdle width & 28.8 & 26.7 & 29.3 & 28.1 & 0.9 \\
\hline \multicolumn{7}{|c|}{ Percents of Head Length } \\
\hline IOD & Interorbital distance & 55.4 & 44.1 & 56.0 & 51.4 & 3.6 \\
\hline OD & Orbital diameter & 8.2 & 8.2 & 12.2 & 10.5 & 1.4 \\
\hline $\mathrm{SnL}$ & Snout length & 35.8 & 27.9 & 36.5 & 31.4 & 2.8 \\
\hline MW & Mouth width & 92.2 & 70.5 & 94.6 & 85.7 & 9.3 \\
\hline MBL & Maxillary barbel length & 75.5 & 65.9 & 102.3 & 87.5 & 12.4 \\
\hline APND & Anterior to posterior nostril distance & 20.8 & 13.7 & 21.3 & 18.6 & 2.4 \\
\hline DPN & Distance between posterior nostrils & 46.3 & 40.5 & 52.3 & 46.3 & 3.7 \\
\hline DPNO & Posterior nostril to orbit distance & 11.6 & 8.8 & 12.6 & 10.7 & 1.1 \\
\hline
\end{tabular}

without posterior projection (Fig. 4C). Dentary tooth plate elongated, larger, and narrower than premaxillary plate.

Frontal bone between mesethmoid and parieto-supraoccipital, defines lateral and posterior margin of anterior cranial fontanelle. Frontals narrow anteriorly and widened from center to back.

Parieto-supraoccipital is pentagon-shaped, in dorsal view, articulates anteriorly with frontals, and continues posterior as a process elongated and pointed, not bifurcate. Parieto-supraoccipital articulates anteriorly with sphenotic, in the center with pterotic and posterior with epiotic.

In ventral view, Weberian apparatus (complex centra) shows the transverse processes 
TABLE 2 I Morphometric data of newly captured specimens of Microglanis variegatus, expressed as percentages of standard length and percentages of head length, $\mathrm{n}=12$ (SD: standard deviation).

\begin{tabular}{|c|c|c|c|c|c|}
\hline & Characters & Min & Max & Mean & \pm SD \\
\hline SL & Standard Length (mm) & 25.8 & 37.9 & & \\
\hline \multicolumn{6}{|c|}{ Percents of Standard Length } \\
\hline HL & Head length & 24.0 & 31.8 & 29.2 & 2.2 \\
\hline $\mathrm{PL}$ & Pelvic fin length & 16.5 & 18.7 & 17.7 & 0.6 \\
\hline DBL & Dorsal-fin spine length & 10.8 & 14.9 & 12.9 & 1.3 \\
\hline PSL & Pectoral-fin spine length & 14.2 & 17.8 & 15.9 & 1.1 \\
\hline LPCP & Length of postcleithral process & 10.3 & 12.8 & 11.4 & 0.7 \\
\hline PDD & Predorsal distance & 36.1 & 39.3 & 37.9 & 1.0 \\
\hline PPL & Prepelvic length & 47.3 & 53.0 & 50.2 & 1.6 \\
\hline AAnD & Anus to anal fin distance & 10.9 & 14.5 & 13.2 & 1.1 \\
\hline $\mathrm{CPL}$ & Caudal peduncle length & 13.3 & 16.7 & 15.2 & 1.1 \\
\hline $\mathrm{CPD}$ & Caudal peduncle depth & 11.4 & 15.3 & 13.5 & 1.3 \\
\hline $\mathrm{BD}$ & Body depth & 18.0 & 22.9 & 20.9 & 1.3 \\
\hline DBL & Dorsal-fin base length & 10.8 & 14.9 & 12.9 & 1.3 \\
\hline AdBL & Adipose-fin base length & 16.9 & 25.5 & 21.4 & 3.0 \\
\hline AnBL & Anal-fin base length & 11.8 & 15.9 & 13.1 & 1.2 \\
\hline $\mathrm{DP}$ & Distance between pelvic fins & 8.9 & 12.4 & 11.6 & 1.2 \\
\hline DPA & Distance from pelvic fin to anus & 9.0 & 12.7 & 10.5 & 1.1 \\
\hline PAD & Pelvic to anal fin distance & 20.4 & 24.2 & 22.9 & 1.0 \\
\hline DDP & Distance between the dorsal and pelvic fins & 22.0 & 24.1 & 23.1 & 0.7 \\
\hline PGW & Pectoral girdle width & 25.9 & 29.6 & 27.3 & 1.1 \\
\hline \multicolumn{6}{|c|}{ Percents of Head Length } \\
\hline IOD & Interorbital distance & 38.0 & 49.5 & 41.1 & 3.2 \\
\hline OD & Orbital diameter & 10.9 & 15.8 & 13.0 & 1.5 \\
\hline SnL & Snout length & 30.6 & 45.0 & 35.6 & 4.1 \\
\hline MW & Mouth width & 68.4 & 94.3 & 75.1 & 8.3 \\
\hline MBL & Maxillary barbel length & 38.7 & 72.4 & 53.6 & 10.8 \\
\hline APND & Anterior to posterior nostril distance & 11.1 & 18.0 & 14.1 & 1.8 \\
\hline $\mathrm{DPN}$ & Distance between posterior nostrils & 24.4 & 30.6 & 27.4 & 1.6 \\
\hline DPNO & Posterior nostril to orbit distance & 4.7 & 9.2 & 6.5 & 1.3 \\
\hline
\end{tabular}

of 4th centra, expanded as anterior and posterior projections, with a concave margin at the center, anterior and posterior projections not branched, pointed. Frontal region of anterior projection flat or somewhat deflected ventrally. Transverse processes of 5th centra elongated, curved and pointed (Fig. 5). Thirty vertebrae (six precaudal +24 caudal). Six pairs of pleural ribs.

Branchial apparatus with two basibranchial and two hypobranchial elements ossified, visible. Gill rakers small and conical, first branchial arch with 2, 1, 4-5. Branchiostegal rays, 9.

On pectoral girdle, cleitrum with two projections on distal region, one dorsal, pointed, articulates with posttemporosupracleitrum and a posterior projection (cleithral spine), slender and pointed (Fig. 6A). On dorsal view of escapulo-coracoid bone, filamentous mesocoracoid arch is present (Fig. 6A). Tip of pectoral-fin spine not ossified. 
A

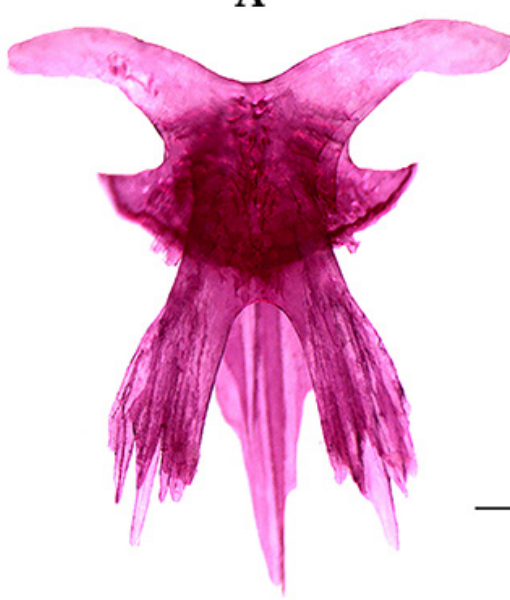

B

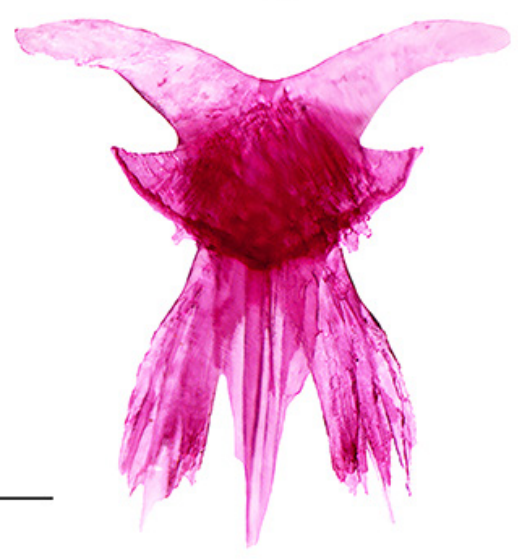

C

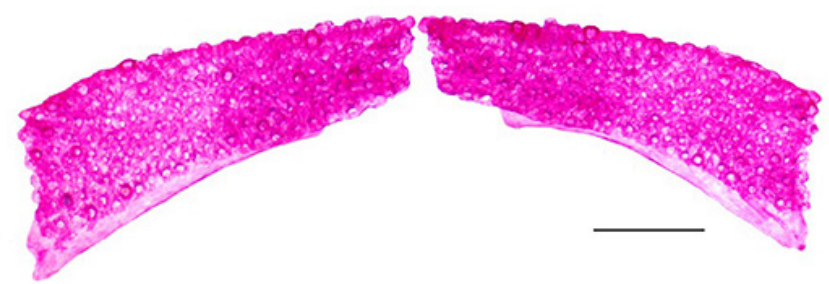

FIGURE 4 I Microglanis berbixae, MECN-DP 3762, paratype, 39.6 mm SL. Mesethmoid-Vomer complex. A. Dorsal view. B. Ventral view. C. Premaxillary tooth plate, ventral view. Scale bars $=1 \mathrm{~mm}$.

Anterior and posterior surfaces of pectoral-fin spine, dentate. Anterior surface with 10-12 small or weakly developed prickles, on the central and proximal sectors, distal sector without prickles Posterior surface of pectoral-fin spine with 10 prickles welldeveloped (Fig. 6B).

Coloration in alcohol. Color pattern on specimens preserved in $70 \%$ ethanol: head and body color, uniform, pale brown, yellowish or grayish, without bands, dots, blotches, or patches, except transverse lunate band, dark brown, or black at the caudalfin base (Fig. 1). Belly color uniform, pale brown, whitish or grayish, without groups of melanophores. Fins without dots, blotches, or bands; rays with very narrow dark brown or black bands or stripes, proximally and medially. Interradial membrane is hyaline, except on dorsal-fin. Dorsal-fin has dark brown interradial membrane, anterior and proximally, becoming paler or hyaline posterior and distally. Adipose-fin similarly colored as head and body, but the border is hyaline, its origin and forward without lighter or luminous areas. Three specimens with two or three dark brown or black dots, usually horizontally aligned.

Sexual dimorphism. Specimens analyzed have urogenital papilla easily detected behind anus. The papilla is a short tube, thick and fleshy, with cylindrical or triangular shape. Cylindrical-shaped papilla ending truncate with a small pointed flap is associated with females (Fig. 7A). Two of them were dissected, showing well-developed 


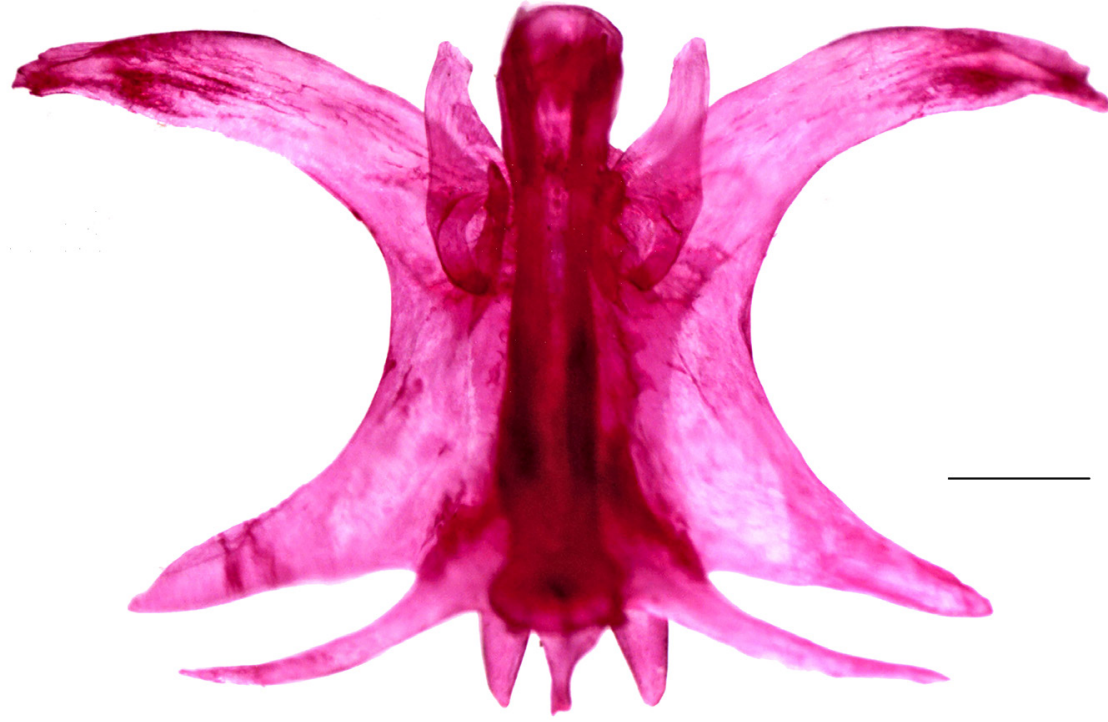

FIGURE 5 I Microglanis berbixae, MECN-DP 3762, paratype, $39.6 \mathrm{~mm}$ SL. Ventral view Weberian apparatus. Scale bar $=1 \mathrm{~mm}$.

A

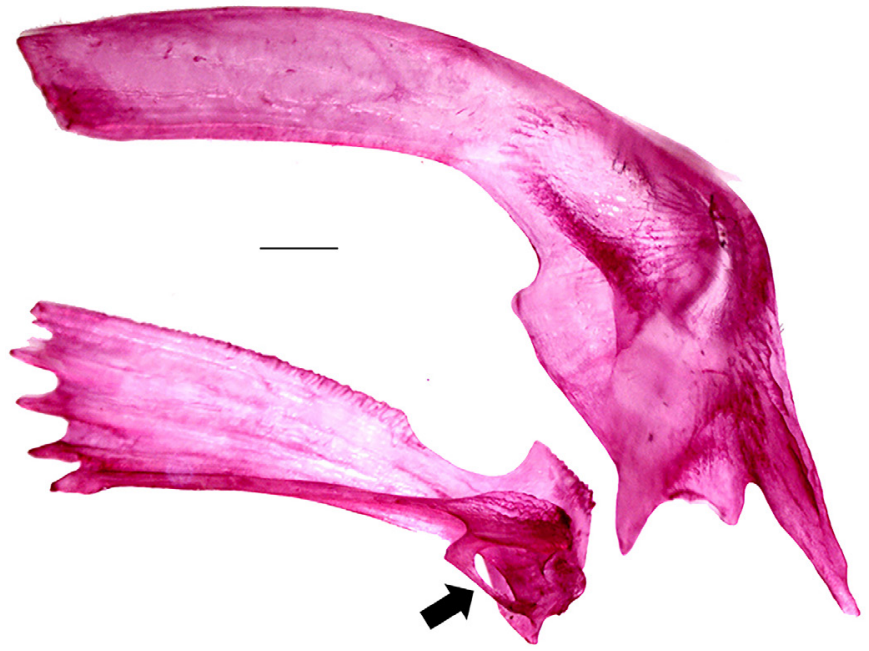

B

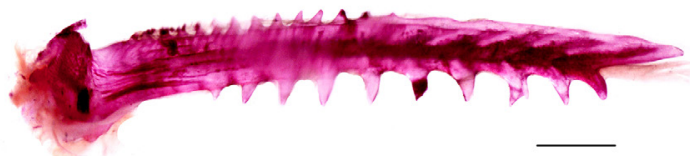

FIGURE 6 | Microglanis berbixae, MECN-DP 3762, paratype, $39.6 \mathrm{~mm}$ SL. A. Dorsal view right pectoral girdle. The arrow shows the filamentous mesocoracoid arch. B. Dorsal view right pectoral-fin spine. Scale bars $=1 \mathrm{~mm}$. 
ovaries, with yellow ovules visible by the naked eye. Ovaries occupy important volume on posterior region of abdominal cavity. Elongate and triangular papilla, ending in point tip associated with male specimens (Fig. 7B). One dissected male specimen showed developed testicles as ramified bands, white, attached to the dorsal region of abdominal cavity.

Geographical distribution. Specimens were captured in two small rivers of the Pachijal River system, the Sune and Mashpi Rivers (Fig. 8). These rivers belong to the Esmeraldas River Basin, Pacific Ocean versant, northwestern Ecuador, Pichincha province.

Ecological notes. Specimens were captured from two different localities. Microhabitat preferences: capture zone around the central area of the stream, characterized by shallow rapids (<20 cm; $<0.3 \mathrm{~m} \mathrm{~s}-1)$ with pebbles and small scattered boulders. Sampling area at the Sune River located at 960 masl with a water temperature of $20.3^{\circ} \mathrm{C}$, a conductivity of $46.5 \mu \mathrm{S} \mathrm{cm}-1$, dissolved oxygen with a saturation of $74.9 \%$, and a $\mathrm{pH}$ of 7.8. River stretch with a mean width of $4.2 \mathrm{~m}$ and a mean depth of $33.1 \mathrm{~cm}$. Rapids with slow velocities (< $0.3 \mathrm{~m} \mathrm{~s}-1)$. Substrate composed as follows: sand (<2 mm) 19\%; gravel (2-64 mm) 23.3\%; pebbles (64-256 mm) 21.7\%; boulders (> $256 \mathrm{~mm}$ ) 22.7\%; and bedrock 13.3\%. Riparian forest almost intact, shading 90\% of the stream (Fig. 9). In one sample from the Sune River, the fish community dominated by Rhoadsia altipinna (26 specimens) and Andinoacara blombergi (12). The fish assemblage also included Astroblepus cyclopus (1), Astroblepus sp. (3), Trichomycterus sp. (2), Pseudopoecilia festae (2), and Microglanis berbixae (12).

At the Mashpi River, specimens were captured from the mouth of a small stream draining to the main channel, at 562 masl. Pphysicochemical variables were: water temperature of $23.2^{\circ} \mathrm{C}$, a conductivity of $78.7 \mu \mathrm{S} \mathrm{cm}-1$, dissolved oxygen with a saturation of $89.4 \%$, and a $\mathrm{pH}$ of 7.8 . River stretch with a mean width of $1.9 \mathrm{~m}$ and a mean depth of $13.1 \mathrm{~cm}$, mainly dominated by shallow rapids with slow velocities $(<0.3 \mathrm{~m}$ $\mathrm{s}-1)$. Substrate composed by: sand $(<2 \mathrm{~mm}) 55 \%$; gravel $(2-64 \mathrm{~mm}) 13 \%$; pebbles

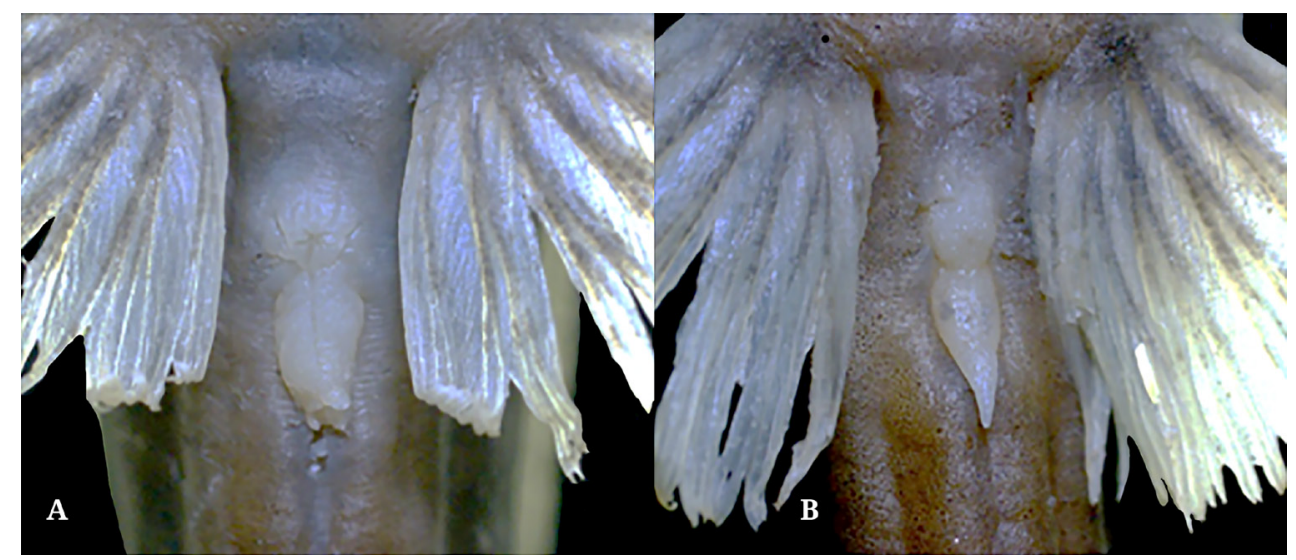

FIGURE 7 I Microglanis berbixae, close up urogenital papillae. A. Female, MECN-DP-3765, 53.5 mm SL. B. Male, MECN-DP-3765, $52.6 \mathrm{~mm}$ SL. 


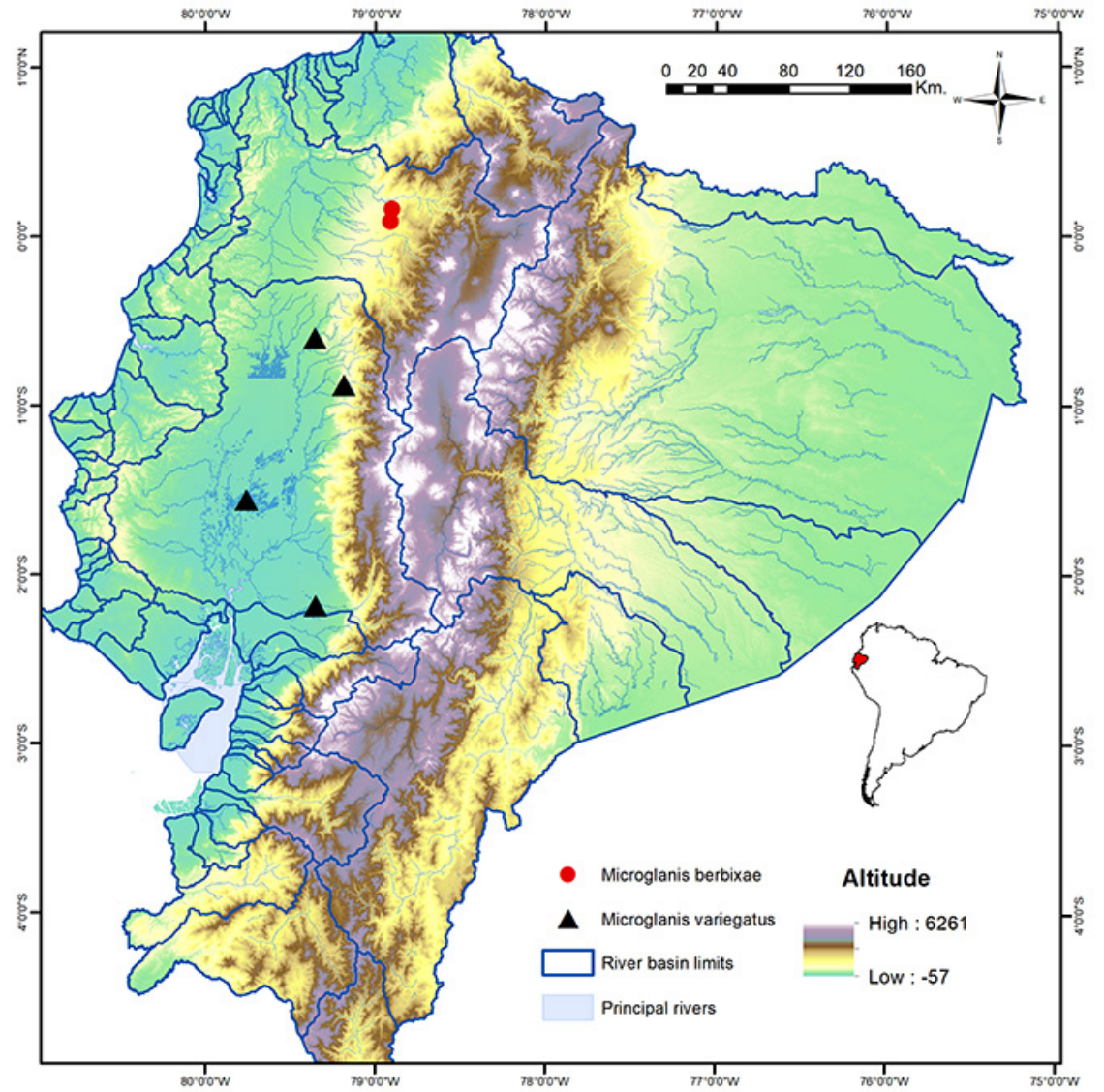

FIGURE 8 I Map of Ecuador showing capture localities of Microglanis berbixae (red dots) and Microglanis variegatus (black triangles).

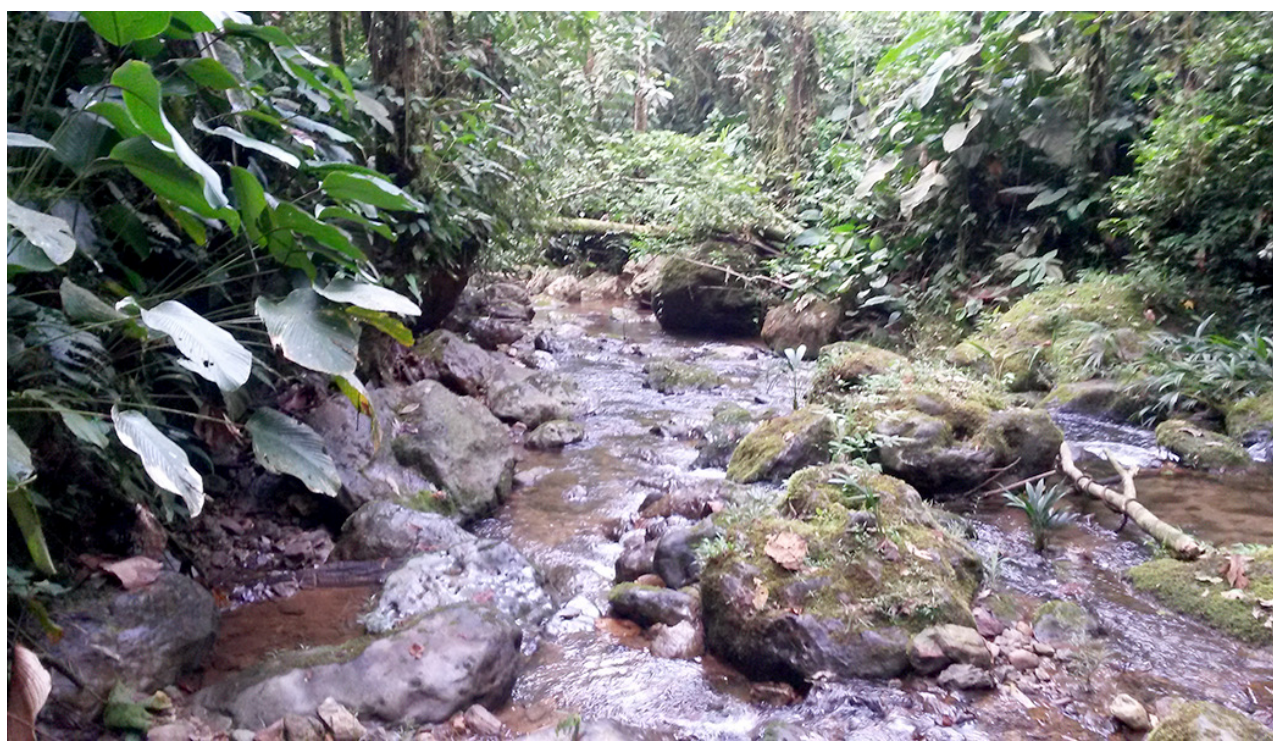

FIGURE 9 I Quebrada Sune, tributary of Pachijal River, Pichincha. Type locality of Microglanis berbixae. 
(64-256 mm) 7\%; and boulders (> $256 \mathrm{~mm}$ ) 25\%. The stretch totally shaded by a wellpreserved riparian forest. In one sample, the fish community composed by: Rhoadsia altipinna (15 specimens), Andinoacara blombergi (1), Bryconamericus dahli (3), Astroblepus sp. (2), Trichomycterus sp. (1), Pimelodella modesta (2) and Microglanis berbixae (1).

Etymology. The specific name "berbixae", honor María Resurección Sesma Lizari, "Berbixe", mother of Ibon Tobes Sesma, for its unconditional support and infinite love. A genitive.

Conservation status. Microglanis berbixae inhabits the Tropical Andes at the Pacific slope of Ecuador. This area belongs to the Tumbes-Chocó-Magdalena hotspot (Myers et al., 2000). The Pachijal River system drains to the Esmeraldas River basin, coastal slope of northwestern Ecuador. In the area, river systems are poorly known and Microglanis berbixae has been reported for only two localities. Consequently, the conservation status of Microglanis berbixae may be classified as Data Deficient (DD), according to the International Union for Conservation of Nature (IUCN) categories and criteria (IUCN, 2019).

Morphometric comparison. After comparing the 28 morphometric characteristics between $M$. berbixae and $M$. variegatus, only two variables show intervals without overlap: the distance between dorsal and pelvic fins and the distance between posterior nostrils (see Tabs. 1-2).

\section{DISCUSSION}

Microglanis berbixae belongs to the family Pseudopimelodidae without any doubt. The external characteristics of the specimens determine this conclusion. However, the generic allocation of the species is controversial, therefore, is included tentatively in the genus Microglanis based on the results of the comparative analyses. First, we compared it with the three species and three genera of Pseudopimelodidae that inhabit the Pacific slope of Colombia and Ecuador (Fricke et al., 2020): Batrochoglanis transmontanus, Cruciglanis pacifici and Microglanis variegatus. Microglanis berbixae has uniform color pattern of head and body, while the color pattern of head and body of the other three species presents spots, bands or dots. The caudal-fin of M. berbixae is truncated, in B. transmontanus and C. pacifici is emarginated, and in $M$. variegatus the caudal-fin is emarginated or truncated with slightly rounded tips. The lateral line is incomplete and short in all species; in M. berbixae and M. variegatus it only reaches the origin of the pelvic-fin, while in B.transmontanus and C. pacifici, lateral line surpasses the base of the pelvic-fin (Regan, 1913; Eigenmann et al., 1914; Ortega-Lara, Lehmann, 2006). These results indicate that specimens of $M$. berbixae are more like $M$. variegatus, but present some significant differences.

When some osteological characters of $M$. berbixae are compare with those reported for species of Microglanis, B. transmontanus and C. pacifici, the results show: In M. berbixae the vomer is fused with the mesethmoides. Lundberg et al. (1991) indicate that the vomer is absent in Lophiosilurus, Microglanis and Batrochoglanis, probably due to 
fusion with the mesethmoid. Sarmento-Soares et al. (2006) point out that the vomer is ovoid and wide in M. pataxo and located between the cartilaginous wings of the lateral ethmoid, in contact with the mesetmoid dorsally. Ortega-Lara, Lehmann (2006) indicate a T-shaped vomer present in C. pacifici, but do not show or indicate the presence of the vomer in B. transmontanus and $M$. iheringi. The condition observed in $M$. berbixae supports the conclusion of Lundberg et al. (1991), but conditions reported in other species of Microglanis indicate that the fusion of mesetmoid and vomer may be variable. In M. berbixae and C. pacifici the distal margin of premaxillary tooth plate is wide and without a posterior projection; in B. transmontanus the distal margin is curved and projecting backwards, while in species of Microglanis the premaxillary tooth plate is rectangular (Ortega-Lara, Lehmann, 2006; Ruiz, 2016; Shibatta, 2016). In M. berbixae and species of Microglanis, the anterior cranial fontanelle is elliptical and wide, while in B. transmontanus is short and narrow, and in C. pacifici is elongated and narrow (Ortega-Lara, Lehmann, 2006; Ruiz, 2016; Shibatta, 2016). In M. berbixae the posterior region or the posterior process of parieto-supraoccipital is elongated and pointed, not forked. A similar condition is indicated for M. iheringi (Ortega-Lara, Lehmann, 2006); but in M. pataxo and M. pleriqueater the posterior process of parieto-supraoccipital is short and bifurcated (Sarmento-Soares et al., 2006; Mattos et al., 2013). Ruiz, Shibatta (2010) point out that a short posterior process on the parieto-supraoccipital is diagnostic for species of Microglanis. At the pectoral girdle, $M$. berbixae has a filamentous mesocoracoid arch; this condition is diagnostic for the species of Microglanis (Ruiz, Shibatta, 2010; Ruiz, 2016).

The evaluation of the external and osteological characteristics of $M$. berbixae suggests its inclusion in Microglanis, tentatively, waiting further analyses to determine its appropriate generic status. On the other hand, observed variability on bone components determines the need to improve studies on the osteology to know the variation interval between species of the genus Microglanis.

Among the species included in the genus Microglanis, M. berbixae can be easily recognized. Unlike its congeners, M. berbixae has a uniform body color pattern, making inappropriate the name bumblebee catfish for them, while other species traditionally included in Microglanis have a variable body color pattern, with colored transverse bands or bars and blotches. Shibatta $(2014,2016)$ and Ruiz (2016) point out that this color pattern is one of the diagnostic characteristics for Microglanis. Microglanis berbixae and $M$. variegatus have evident differences in terms of external morphology, but among morphometric variables differences are small and the majority of measurements overlap. A comparative analysis on osteology is ongoing between M. berbixae and M. variegatus, to establish the relationships between them and with other species of Microglanis.

Microglanis berbixae and M. variegatus inhabit the Pacific slope of Ecuador and could be phylogenetically related species. Provenzano, Barriga (2017) provide a similar example with two species of Hemiancistrus that inhabit the same region. Phylogenetic analyses for the species inhabiting the cis-Andean region are required to establish hypotheses of these relationships. These hypotheses and the available knowledge on the geological, climatic or other environmental events (e.g. river capture) could explain the speciation processes that took place in the area, throwing some light to the species diversity and distribution patterns observed nowadays in the Pacific slope of Ecuador. 
Comparative material examined. Batrochoglanis transmontanus: Ecuador, Esmeraldas Province: MEPN 3817, 5, 25.4-37.8 mm SL, Parroquia Selva Alegre, Santiago River system. Microglanis variegatus: Ecuador, Guayas Province: MECN-DP-1489, 7, 16.6-26.3 mm SL, Río Vinces; MECN-DP-3942, 1, 31.3 mm SL, Río Chimbo. Los Ríos Province: MECN-DP-4259, 12, 25.8-37.9 mm SL, Río Baba. Cotopaxi Province: MZUTI-P-626, 1, 35.66 mm SL, Tontomalo River.

\section{ACKNOWLEDGMENTS}

We express our gratitude to Universidad Tecnológica Indoamérica and International Watershed Partners for support and funding to carrying out this research. Thanks to Fundación Imaymana, Reserva Pambiliño, Bosque Privado Jardín de los Sueños, Chocolate Mashpi and Mashpi Lodge for their logistic support during our fieldwork. We thank Ramiro Barriga, Colección de Peces, Museo de la Escuela Politécnica Nacional (Quito, Ecuador), Armando Ortega, Windsor Aguirre, Daniela Franco and Carolina Carrillo, for advice and support. Thanks to Donald Taphorn for the language editing and useful suggestions. Thanks to the Research Center for Territory and Sustainable Habitat of the Universidad Tecnológica Indoamérica (Quito, Ecuador), for its support in the cartography elaboration (Fig. 8) and to Jaime Culebras (Fig. 1), Jose Vieira (Fig. 2-3B) and Carlos Morochz (Fig. 3A) for the photographs. We are grateful to Blanca Ríos and Rafael Miranda for their support and to all people that helped us during the research process.

\section{REFERENCES}

- Ahl E. Beschreibung dreier neuer welse aus Brasilien. Zool Anz. 1936; 116(3/4):10911.

- Alcaraz HSV, Graça WJ, Shibatta OA. Microglanis carlae, a new species of bumblebee catfish (Siluriformes: Pseudopimelodidae) from the río Paraguay basin in Paraguay. Neotrop Ichthyol. 2008; 6(3):425-32. http://dx.doi.org/10.1590/ S1679-62252008000300016

- Barriga R. Lista de peces de agua dulce e intermareales del Ecuador. Rev Politec. 2012; 30(3):83-119.

- Bertaco VA, Cardoso AR. A new species of Microglanis (Siluriformes: Pseudopimelodidae) from the Rio Uruguay drainage, Brazil. Neotrop Ichthyol. 2005; 3(1):61-67. http://dx.doi.org/10.1590/S167962252005000100002

- Bizerril CRSF, Perez-Neto PR. Description of a new species of Microglanis (Siluroidei, Pimelodidae) from eastern Brazil. RFAH. 1992; 18(4):97-100.
- Boulenger GA. An account of the siluroid fishes obtained by Dr. H. von Ihering and Herr Sebastian Wolff in the Province Rio Grande do Sul, Brazil. Proc Zool Soc London. 1891; 59(2):231-35, pls. 25-26.

- Eigenmann $\mathbf{C H}$. The freshwater fishes of British Guiana, including a study of the ecological grouping of species, and the relation of the fauna of the plateau to that of the lowlands. Mem Carnegie Mus. 1912; 5(1):1-578, pls. 1-103. http://dx.doi. org/10.5962/bhl.part.14515

- Eigenmann CH, Henn AW, Wilson C. New fishes from western Colombia, Ecuador, and Peru. (Contrib. Zool. Lab. Ind. Univ. No. 133.). Indiana Univ Stud. 1914; 19:1-15.

- Eigenmann CH, Allen WR. Fishes of Western South America. I. The intercordilleran and Amazonian lowlands of Peru. II. The high pampas of Peru, Bolivia, and northern Chile. With a revision of the Peruvian Gymnotidae, and of the genus Orestias. Lexington: University of Kentucky; 1942. 
- Fricke R, Eschmeyer WN, Van der Laan R, editors. Eschmeyer's Catalog of fishes: genera, species, references [Internet]. San Francisco: California Academy of Science; 2020. Available from http:// researcharchive.calacademy.org/research/ ichthyology/catalog/fishcatmain.asp

- Gomes AL. A review of Microglanis, a genus of South American catfishes, with notes of related genera. Occ Pap Mus Zool. 1946; 494:1-19.

- International Union for Conservation of Nature (IUCN). Standards and Petitions Subcommittee. Guidelines for using the IUCN Red List Categories and Criteria, Version 13 [Internet]. 2019. Available from: http://www.iucnredlist.org/documents/ RedListGuidelines.pdf

- Jarduli LR, Shibatta OA. Description of a new species of Microglanis (Siluriformes: Pseudopimelodidae) from the Amazon basin, Amazonas State, Brazil. Neotrop Ichthyol. 2013; 11(3):507-12. http://dx.doi. org/10.1590/S1679-62252013000300004

- Jiménez-Prado P, Aguirre W, LaazMoncayo E, Navarrete-Amaya R, NugraSalazar F, Rebolledo-Monsalve E et al. Guía de peces para aguas continentales en la vertiente occidental del Ecuador. Esmeraldas: Pontificia Universidad Católica del Ecuador Sede Esmeraldas (PUCESE), Universidad del Azuay (UDA) y Museo Ecuatoriano de Ciencias Naturales del Instituto Nacional de Biodiversidad (MECNINB); 2015.

- Lundberg JG, Bornbusch AH, MagoLeccia F. Gladioglanis conquistador $\mathrm{n}$. sp. from Ecuador with diagnoses of the subfamilies Rhamdiinae Bleeker and Pseudopimelodinae n. subf. (Siluriformes: Pimelodidae). Copeia. 1991:190-209. http:// dx.doi.org/10.2307/1446263

- Malabarba LR, Mahler JKF Jr. Review of the genus Microglanis in the Rio Uruguay and coastal drainages of southern Brazil (Ostariophysi: Pimelodidae). Ichthyol Explor Freshw. 1998; 9:243-54.

- Mattos JLO, Ottoni FP, Barbosa MA. Microglanis pleriqueater, a new species of catfish from the São João river basin, eastern Brazil (Teleostei: Pseudopimelodidae). Ichthyol Explor Freshw. 2013; 24(2):147-54.

- Mees GF. The Auchenipteridae and Pimelodidae of Suriname (Pisces, Nematognathi). Zool Verh (Leiden). 1974; 132:1-256.
- Mees GF. Two new species of Pimelodidae from northwestern South America (Pisces, Nematognathi). Zool Med Leiden. 1978; 53(23):253-61.

- Myers N, Mittermeier RA, Mittermeier CG, Da Fonseca GA, Kent J. Biodiversity hotspots for conservation priorities. Nature, 2000; 403(6772):853. http://dx.doi. org/10.1038/35002501

- Ortega-Lara A, Lehmann A. Cruciglanis, a new genus of Pseudopimelodid catfish (Ostariophysi: Siluriformes) with description of a new species from the Colombian Pacific coast. Neotrop Ichthyol. 2006; 4(2):147-56. http://dx.doi.org/10.1590/ S1679-62252006000200002

- Ottoni FP, Mattos JLO, Barbosa MA. Description of a new species of Microglanis from de Rio Barra Seca basin, southeastern Brazil (Teleostei: Siluriformes: Pseudopimelodidae). Vertebr Zool. 2010; 60(3):187-92.

- Provenzano F, Barriga R. The species of Hemiancistrus (Siluriformes: Loricariidae) from Ecuador. Zootaxa. 2017; 4272(2):221-35. http://dx.doi.org/10.11646/ zootaxa.4272.2.4

- Regan CT. The fishes of the San Juan River, Colombia. Ann Mag Nat Hist. (ser. 8) 1913; 12(71):462-73. http://dx.doi. org/10.1080/00222931308693424

- Ruiz WBG. Three new species of catfishes of the genus Microglanis from Brazil (Teleostei: Pseudopimelodidae), with comments on the characters used within the genus. Ichthyol Explor Freshw. 2016; 27(3):211-32.

- Ruiz WBG, Shibatta OA. A new species of Microglanis (Siluriformes: Pseudopimelodidae) from lower Rio Tocantins basin, Pará, Brazil, with a description of superficial neuromasts and pores of lateral line system. Zootaxa. 2010; 2632(1):53-66. http://dx.doi.org/10.11646/ zootaxa.2632.1.3

- Ruiz WBG, Shibatta OA. Two new species of Microglanis (Siluriformes: Pseudopimelodidae) from the uppermiddle rio Araguaia basin, Central Brazil. Neotrop Ichthyol. 2011; 9(4):697-707. http://dx.doi.org/10.1590/S167962252011000400002 
- Sabaj MH. Standard symbolic codes for institutional resource collections in herpetology and ichthyology: an online reference [Internet]. Washington: American Society of Ichthyologists and Herpetologists; 2016. Available from: https://asih.org/sites/default/ files/documents/symbolic_codes_for_ collections_v6.5_2016.pdf

- Sarmento-Soares LM, Martins-Pinheiro RF, Aranda AT, Chamon CC. Microglanis pataxo, a new catfish from southern Bahia coastal rivers, northeastern Brazil (Siluriformes: Pseudopimelodidae). Neotrop Ichthyol. 2006; 4(2):157-66. http://dx.doi.org/10.1590/S167962252006000200003

- Shibatta OA. Family Pseudopimelodidae (Bumblebee catfishes, dwarf marbled catfishes). In: Reis RE, Kullander SO, Ferraris CJ, Jr., editors. Checklist of the freshwater fishes of South and Central America. Porto Alegre: Edipucrs; 2003.

- Shibatta OA. A new species of Microglanis (Siluriformes, Pseudopimelodidae) from the upper Rio Tocantins basin, Goiás state, Central Brazil. Neotrop Ichthyol. 2014; 12(1):81-87. http://dx.doi.org/10.1590/ S1679-62252014000100008

- Shibatta OA. A new species of bumblebee catfish of the genus Microglanis (Siluriformes: Pseudopimelodidae) from the upper Rio Paraguay basin, Brazil. Neotrop Ichthyol. 2016; 14(3):525-32. http:// dx.doi.org/10.1590/1982-0224-20160031
- Shibatta OA, Benine RC. A new species of Microglanis (Siluriformes: Pseudopimelodidae) from upper Rio Paraná basin, Brazil. Neotrop Ichthyol. 2005; 3(4):579-85. http://dx.doi.org/10.1590/ S1679-62252005000400015

- Shibatta OA, Vari RP. A new genus of Neotropical rheophilic catfishes, with four new species (Teleostei: Siluriformes: Pseudopimelodidae). Neotrop Ichthyol. 2017; 15(2). http://dx.doi.org/10.1590/19820224-20160132

- Steindachner F. Denkschr Kaiser Akad Wissens Wien. 1880; 42:55-104, pls. 1-9.

- Taylor WR, Van Dyke GC. Revised procedures for staining and clearing small fishes and other vertebrates for bone and cartilage study. Cybium. 1985; 9:107-09.

- Terán GE, Jarduli LR, Alonso F, Mirande JM, Shibatta OA. Microglanis nigrolineatus, a new species from northwestern Argentina (Ostariophysi: Pseudopimelodidae). Ichthyol Explor Freshw. 2016; 27(3):193-202.

\section{AUTHOR'S CONTRIBUTION @}

Ibon Tobes: Conceptualization, Data curation, Formal analysis, Funding acquisition, Investigation, Methodology, Project administration, Resources, Software, Supervision, Validation, Visualization, Writingoriginal draft, Writing-review \& editing.

Ana Falconí-López: Data curation, Formal analysis, Investigation, Methodology, Resources, Validation, Visualization, Writing-original draft, Writing-review \& editing.

Jonathan Valdiviezo: Data curation, Formal analysis, Investigation, Methodology, Resources, Software, Supervision, Validation, Visualization, Writing-original draft, Writing-review \& editing.

Francisco Provenzano: Conceptualization, Data curation, Formal analysis, Investigation, Methodology, Project administration, Supervision, Validation, Writing-original draft, Writing-review \& editing.

\section{ETHICAL STATEMENT}

Samplings were approved by the Ministerio del Ambiente by the permit NO. 008-2016-IC-FAU-DPAPMA. 


\section{Neotropical |chthyology}

$$
\text { OPEN } \partial \text { ACCESS }
$$

\section{(c) (1)}

This is an open access article under the terms of the Creach, use, distribution and reproduction in any medium,

Distributed under

Creative Commons CC-BY 4.0

(1) 2020 The Authors.

Diversity and Distributions Published by SBI

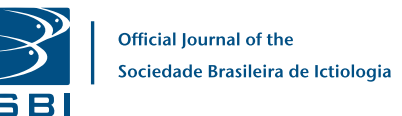

SBI

\section{COMPETING INTERESTS}

The authors declare no competing interests.

HOW TO CITE THIS ARTICLE

- Tobes I, Falconí-López A, Valdiviezo-Rivera J, Provenzano-Rizzi F. A new species of Microglanis (Siluriformes: Pseudopimelodidae) from the Pacific slope of Ecuador. Neotrop Ichthyol. 2020; 18(2):e190023. https://doi.org/10.1590/1982-0224-2019-0023 